\title{
DESCRIPTION OF A NEW CROTON, FROM NEW SOUTH WALES.
}

\author{
By J. H. Maiden, F.L.S., and R. T. Baker, F.L.S.
}

\author{
(Plate XII.)
}

\section{Croton affinis, sp.nov.}

A small tree, glabrous or with stellate scales on the new growth whether twigs or leaves as in C. acronychioides, sometimes slightly hispid or scurfy ; the stellate scales scattered on the young leaves but absent on the older ones.

Leaves thin, with numerous transparent dots, broadly lanceo_ late to elliptical or ovate, not obtuse; distinctly but not deeply dentate, rarely entire; usually about 3 inches long, but occurring up to over 6 inches long and $2 \frac{1}{2}$ broad, slightly paler on the underside, penninerved, finely veined; petiole channelled above, from $\frac{1}{4}$ to $\frac{1}{2}$ inch long; basal glands sessile.

Racemes 1 to 2 inches long as far as seen, terminal, the basal cluster consisting mostly of females, the upper flowers being nearly all males; pedicels varying in length from 2 to 4 lines; bracts 1 to 2 lines long.

Sepals of male flowers scarcely obtuse, imbricate in the bud, ciliate on the upper edges; petals small, narrow, ciliate ; stamens 5 or 6 , inflexed, filaments shorter than those of $C$. acronychioides, receptacle very hairy.

Calyx of the female flowers persistent under the capsule; segments hardly obtuse, broad. Ovary densely hairy. Styles divided to near the base into three branches, which are again divided and subdivided to an apparently variable extent. 
Capsule tridymous, furrowed, sprinkled with stellate scales; about 3 lines long and 6 lines broad; slightly depressed at the top. Hab.-Banks of a rocky creek, near Tintenbar, Richmond River, New South Wales (W. Bäuerlen).

This species is most closely related to two Queensland species, $C$. acronychioides and C. triacros, and is quite distinct from any New South Wales Croton.

It differs from $C$. acronychioides and $C$. triacros in the texture of its leaves, which are thin; the pedicels are also much longer. In regard to the number of stamens, it has usually 5, and apparently never more than 6 , while $C$. acronychioides may have as many as 8, and C. triacros as many as 10 .

The stamens of $C$. acronychioides are longer than those of our species.

In the Flora Australiensis there is no reference to petals in either $C$. acronychioides or $C$. triacros, but in our species they are marked.

The persistent calyx under the fruit is also to be noted, as among Australian Crotons it appears only to be present in $C$. opponens.

The capsule of $C$. acronychioides is described as "longer than broad, scarcely furrowed." The dimensions given above for the capsule of our new species will show that such a description does not apply to its fruit. As a matter of fact, the fruit of our species is both furrowed and deeply lobed, in which respect it resembles that of $C$. triacros.

\section{ABBREVIATED ANALYSIS.}

C. acronychioides.-Leaves coriaceous. Stamens 5 to 8. Capsule longer than broad, scarcely furrowed.

C. n.sp.-Leaves thin. Stamens 5, rarely 6. Capsule broader than long, 3-lobed and furrowed.

C. triacros.-Leaves coriaceous. Stamens about 10. Capsule deeply 3-lobed at the top and 3-furrowed. 


\section{EXPLANATION OF PLATE.}

Fig. 1.-Unexpanded pedunculate male flower.

Figs. 2 and 3.-Stamens, back and front view.

Fig. 4.-Expanded male flower.

Fig. 5.-Female flower.

Fig. 6.-Petal.

Fig. 7.-Fruit capsule showing persistent calyx and stellate scales.

Fig. 8.-Fruit viewed from underside.

Figs. 9, 10 and 11.-Seed.

All enlarged to various extent except fruit capsule. 


\section{$2 \mathrm{BHL}$ Biodiversity Heritage Library}

Maiden, J. H. and Baker, Richard T. 1894. "Description of a new Croton, from New South Wales." Proceedings of the Linnean Society of New South Wales 9, 160-162. https://doi.org/10.5962/bhl.part.18103.

View This Item Online: https://www.biodiversitylibrary.org/item/29750

DOI: https://doi.org/10.5962/bhl.part.18103

Permalink: https://www.biodiversitylibrary.org/partpdf/18103

\section{Holding Institution}

MBLWHOI Library

\section{Sponsored by}

MBLWHOI Library

\section{Copyright \& Reuse}

Copyright Status: NOT_IN_COPYRIGHT

This document was created from content at the Biodiversity Heritage Library, the world's largest open access digital library for biodiversity literature and archives. Visit BHL at https://www.biodiversitylibrary.org. 